\title{
What You Always Wanted to Know About the Accounting Provisions OF THE FOREIGN CORRUPT PRACTICES ACT (BUT WeRE AFRAID TO ASK)
}

\author{
MichaEl S. SPINDLER ${ }^{\bullet}$
}

The Foreign Corrupt Practices Act (FCPA) is the focus of this practical guide to safeguarding against improper business payments. The reader is provided with $a$ brief history of the FCPA, along with an examination of the Act's objectives and recordkeeping requirements. Methods of ensuring compliance with the FCPA are suggested, with a focus on the communication of standards to domestic and foreign employees, agents, associates and officers.
La Foreign Corrupt Practices Act (FCPA) fait l'objet de ce guide pratique contre les versements irréguliers. Il propose une brève histoire de la FCPA, ainsi qu'un examen de ses objectifs et des obligations de tenir des registres. Il suggère enfin plusieurs méthodes visant à assurer le respect de la loi et met en particulier l'accent sur la diffusion des normes parmi les employés, les agents, les associés et les administrateurs tant à l'intérieur du pays qu'à lëtranger.

\section{TABLE OF CONTENTS}

I. INTRODUCTION .....................474

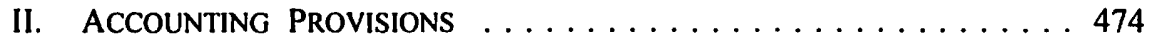

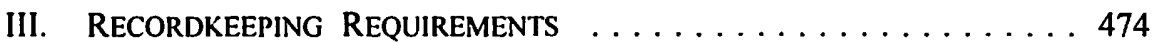

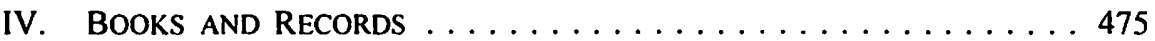

V. INTERNAL CONTROL OBJECTIVES $\ldots \ldots \ldots \ldots \ldots \ldots \ldots \ldots 476$

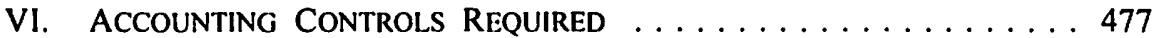

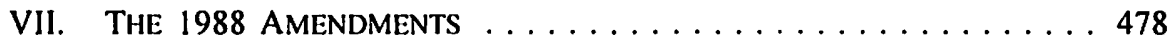

VIII. IMPACT OF THE PRIVATE SECURITIES LITIGATION

REFORM ACT OF $1995 \ldots \ldots \ldots \ldots \ldots$. . . . . . . . . . 478

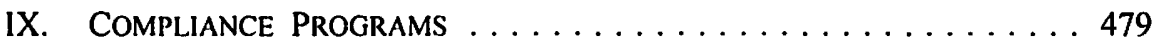

X. APPLYING SENTENCING GUIDELINES

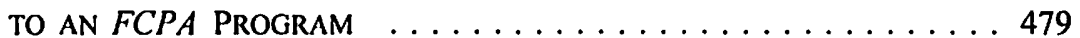

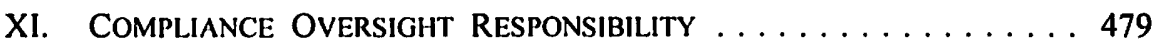

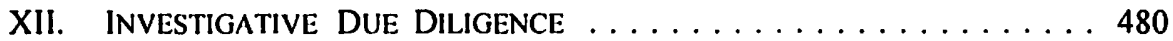

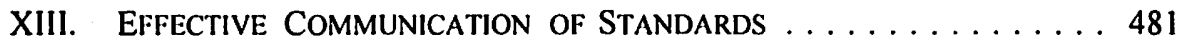

XIV. REASONABLE STEPS TO

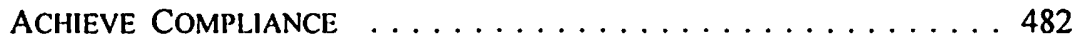

$X V . \quad$ DISCIPLINE AND INCENTIVES $\ldots \ldots \ldots \ldots \ldots \ldots \ldots \ldots 482$

XVI. INDUSTRY Practice, DUE Diligence

AND EFFECTIVE PROCEDURES $\ldots \ldots \ldots \ldots \ldots \ldots \ldots \ldots \ldots$

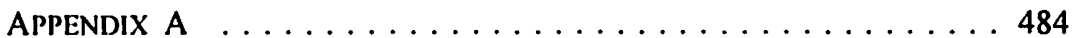

Partner-in-charge, Business Fraud and Investigation Services, U.S. Western Region, Arthur Andersen LLP, Los Angeles office. The author wishes to gratefully acknowledge the efforts of Kimberly K. Smith in the writing of this article. ${ }^{\circ} 1997$ Arthur Andersen. All rights reserved. The views expressed herein are the author's and not nessearily those of Arthur Andersen. The content of this document is intended as general information regarding the subject and should not be taken as professional advice. The reader should consult with counsel or other professional advisor with questions regarding the reader's specific circumstances. 


\section{INTRODUCTION}

Much has been written since the advent of the Foreign Corrupt Practices Act.' However, most commentaries have focused on the FCPA's anti-bribery provisions, with scant little published on such critical and disparate topics as the $F C P A$ accounting provisions, the accounting and support for various forms of payments, or what companies are doing in practice to address the risks of $F C P A$ accounting violations. This article attempts to shed some light on these, the darker recesses of the FCPA. (It is assumed that the reader is already familiar with the anti-bribery provisions of the FCPA.)

\section{Accounting Provisions}

Revelations from the Watergate scandal piqued the interest of the U.S. Securities and Exchange Commission (SEC). When it was learned that major U.S. companies had been involved in the bribery of foreign government officials, the SEC decided to learn more, concerned that accounting systems and controls then in place were not effective in preventing such questionable activities. As the SEC began to investigate these practices, it learned that improper payments were being made by a surprising number of public companies and were often accompanied by falsified entries in company books and records. In order to address these concerns, the accounting provisions of the FCPA included both recordkeeping and accounting control requirements. When these provisions are considered in conjunction with the above history and the anti-bribery provisions, the reasons behind them become quite clear.

\section{RECORDKEEPING REQUIREMENTS}

Section 13(b)(2)(A) of the Securities Exchange Act of $1934^{2}$ was added as $\S 78 \mathrm{~m}(\mathrm{~b})(2)(\mathrm{A})$ of the $F C P A$. It specifies that entities shall "make and keep books, records, and accounts, which, in reasonable detail, accurately and fairly reflect the transactions and dispositions of the assets of the issuer."

Since the addition of this provision, in response to the revelations that improper payments were not being properly recorded, the emphasis has been on transactions and dispositions of assets; in other words, these requirements are intended to cover any situation where "anything of value" that is owned or controlled by the company is being provided to a foreign official in order to obtain or retain business. One can never overestimate the ingenuity of fraudsters (at least the clever ones), and the author has received questions regarding an emerging class of bribe: the offer of information in order to obtain or retain business. This information might not even be concerning the company offering the bribe. The question could also be raised with respect to the offer of a bribe that is not accepted. These practices are violations of the FCPA anti-bribery provisions that do not involve traditional concepts of transactions and dispositions of 
assets. The SEC would likely consider these events to be required disclosures under existing law due to the implications regarding management integrity.

\section{BOOKS AND RECORDS}

Some examples of the books and records contemplated by the FCPA are records used in the preparation of quarterly and annual financial statements, including invoices, purchase orders and other sufficient detail to clearly set forth the nature of the transaction. Records that do not involve transactions and dispositions of assets are not within the ambit of the $F C P A$. For example, certain personnel records, such as a resume included in an employee's personnel file, would not typically be included, since they do not involve a transaction.

These books and records should be in "reasonable detail." "Reasonable" includes a level of detail that would satisfy a prudent official in the conduct of his or her own affairs. The key, in the author's view, is whether the company's support for the transaction is sufficiently complete and detailed to provide a clear understanding to the reviewer as to the true business purpose of the transaction. If you were paying your own bills, for example, would you be satisfied that the payment was proper and that you completely understood the transaction and its reasonableness? Does the amount appear to be fair in relation to the nature of the transaction? Using the example of your own phone bill, does the amount of the bill appear to be reasonable based on the prior bills that you have received and your call volume for the applicable period? Does the bill set forth the long distance calls that you made and the various service options that you selected? Similarly, if the company is paying a consultant for geological survey services, is there a contract that sets forth clearly what services are to be provided? Is the consultant qualified to perform those services? Is the compensation consistent with what the company has historically paid for these services? If not, what is the explanation for the higher or lower rate? Is there evidence that the services were actually performed?

The "reasonable detail" requirement introduces the concept of materiality, one that is often misunderstood in the context of the FCPA. Is a "small" bribe immaterial and, thus, not covered by the FCPA? If the purpose is to obtain or retain business, the implications of even a "small" bribe can be far-reaching. Such a bribe can bring into question management's integrity and the reliability of the company's accounting system and controls. And while the dollar amount offered may not itself be material to the company's financial position, the obvious implication is that the bribe was considered necessary to obtain the contract, project or other business opportunity. That is, the revenue stream, or other benefits, from that opportunity would presumably be significant to the operations of the company or management would not have taken the risk involved. A "small" bribe is a violation of the law, and should not be concealed. Any such attempt would compound the violation of the anti-bribery provisions with a violation of the accounting provisions of the FCPA.

The question is often raised as to how to account for "facilitating payments." Since facilitating payments are not illegal under the $F C P A$, there should be no reason to hide 
them. Any attempt to do so would imply that such payments were actually more sinister in nature. It is submitted that the most appropriate accounting would be based on the nature of the transaction involved. For example, if the payment is made in order to obtain processing of a ministerial function such as approval of a visa application (that would have been approved, but in less timely fashion), the expense should be charged to the account that is used to charge the cost of the visa fee. The underlying support should clearly set forth the nature of the payment. Recognizing the difficulty of obtaining a receipt in such circumstances, there should at least be a document detailing the amount paid, the purpose of the payment and the authorization for the payment.

Some companies consider setting up a separate general ledger account called "facilitating payments" to capture these costs. I would suggest that this practice is less desirable. Failure to use this account for each and every such payment would create an inappropriate implication that the "unrecorded" payment was more sinister than it truly was, if the payment were inadvertently charged to a different account. However, there should be a mechanism in place to collect all such payments so that they may be reviewed by management, and its legal counsel, to ensure that all such payments are proper, both under the FCPA and under local law. In addition, the ability to review such payments collectively will enable the company to take action, where appropriate, to notify the proper authorities. Companies have contributed to the clean-up of customs authorities in certain countries by notifying the U.S. government, which, in turn, was able to notify the applicable foreign government authorities.

\section{INTERNAL CONTROL ObJECTIVES}

The SEC has limited the scope of the records covered by the accounting provisions by stating that, "records which are not related to internal or external audits or to the four internal control objectives set forth in the $[F C P A]$ are not within the purview of the [FCPA's] accounting provisions." ${ }^{3}$ These internal control objectives are as follows:

(1) execute transactions in accordance with management's general or specific authorization;

(2) record transactions as necessary to prepare financial statements in accordance with generally accepted accounting principles and to maintain accountability for assets;

(3) permit access to assets only in accordance with management authorization; and

(4) compare recorded accountability for assets with existing assets at reasonable intervals.

SEC Chairman Williams, Address (SEC Development Conference of the American Institute of Certified Public Accountants, 13 January 1981); published as: SEC, Release \#17,500 (29 January 1981). 
Two themes run throughout these four internal control objectives. The first is the prevention of unrecorded dispositions of company assets. This, of course, addresses the concern that something of value could make its way from the company to a foreign official. The second is that transactions and dispositions must be in accordance with management authorization. In other words, management must take an active role in monitoring and preventing improper payments. If it is discovered that an improper payment has been made and covered up, the company cannot escape liability by claiming that the cover-up was the act of a rogue employee, for that would then mean that either management knew of and authorized the payment, or, if not, then the company's systems and controls allowed for the disposition of assets without the authorization of management, which would then be a violation of the accounting provisions of the FCPA.

\section{ACCOUNTING CONTRols Required}

The FCPA requires methods and records that will:

(1) identify and record all valid transactions;

(2) provide sufficient detail and timeliness to permit proper classification in the proper accounting period;

(3) measure the value of transactions to permit recording the proper monetary value in financial statements; and

(4) present transactions and related disclosures in financial statements.

The controls should remove the company's ability to develop "slush" funds. Illegal payments are effected through two basic schemes: "on-book" schemes and "off-book" schemes. On-book schemes involve a disbursement of company assets that is actually recorded in the books and records; however, its true nature is concealed. For example, a bribe might be made through an intermediary and be recorded as a consulting expense. An off-book scheme involves the disbursement from a hidden pool of funds, such that the transaction is not recorded in any fashion. It can be made from a bank account that has not been recorded on the company's general ledger. Perhaps the bank account has been reflected as closed in the company's records, but funds are still being deposited into it. Perhaps certain of the revenues from a company's sales are being diverted into the account. The existence of such slush funds greatly increases the risk that a company could be in a position to make improper payments.

Improper payments can also be made by improperly measuring the value of transactions. One example is the purchase of a chromite mine from a government official for $\$ 25$ million, when the mine was, in fact, worthless or of little value. Recording the mine as an asset at its $\$ 25$ million price tag would be a violation of the accounting provisions of the FCPA. 


\section{The 1988 AMENDMENTS}

The accounting provisions were affected in several ways by the 1988 amendments to the $F C P A .^{4}$ First, criminal liability for violations of the accounting provisions was limited to those who knowingly circumvent a system of controls or knowingly falsify records kept pursuant to the accounting requirements. This clarified that inadvertent bookkeeping errors would not subject one to criminal liability.

Second, the amendments clarified the registrant's obligations with respect to an uncontrolled affiliate, such as a joint venture interest of less than 50 percent. In such circumstances, the registrant must exercise good faith efforts to use its influence to causes the affiliate to devise and maintain a system of accounting controls consistent with the requirements of the $F C P A$.

\section{IMPACT OF THE PRIVATE SECURITIES LITIGATION REFORM ACT OF 1995}

In SEC Release No. 34-38387 dated 12 March 1997 the SEC adopted final rules intended to implement the reporting requirements in s. 10A of the Exchange Act. In December 1995, s. 10A was added to the Exchange Act as a result of the enactment of Title III, "Auditor Disclosure of Corporate Financial Fraud," of the Private Securities

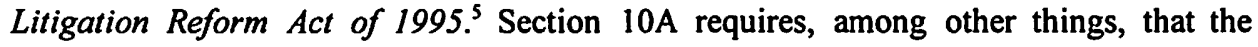
auditor of a registrant's financial statements report to the registrant's board of directors certain uncorrected illegal acts of the registrant, such as an $F C P A$ violation, and that the registrant notify the SEC that it has received such a report. If the registrant fails to provide that notice, the auditor is required by $\mathrm{s}$. $10 \mathrm{~A}$ to furnish directly to the SEC the report given to the board. The SEC is also adopting revisions to Regulation $S-X^{6}$ to conform the definition of an "audit" in that regulation with the wording in s. 10A.

Under the new Rule 10A-1, if an auditor concludes that: (1) a likely illegal act has a material effect on the financial statements, (2) senior management has not taken timely and appropriate remedial action, and (3) the failure to do so is expected to result in a modified report or auditor resignation, the auditor is required to report those conclusions directly to the board of directors. If the board receives such a report, it must notify the SEC within one day after receipt, and furnish a copy of the notification to the auditor. If the auditor fails to receive a copy of the notice within one day, he or she must furnish a copy of the report given to the board (or the documentation of any oral report) to the SEC immediately. An auditor's resignation does not negate the auditor's obligation to furnish the report to the SEC pursuant to Rule 10A-1.

Rule 10A-1 requires that the registrant notification of the illegal act: (1) clearly identify the registrant and the independent accountant, (2) state the date of the 
independent accountant's report to the registrant's board of directors, and (3) provide a summary of the independent accountant's report (description of the likely illegal act and its effect on the financial statements) and a copy of such report.

\section{Complance Programs}

The provisions of the FCPA make it clear that liability cannot be avoided by simply "sticking one's head in the sand" with respect to addressing improper activity. In fact, failure to exercise diligence under certain circumstances can lead to criminal liability. One of the most effective means to reduce the risk of committing FCPA violations is to have a compliance program in place that is both aggressive and clearly communicated to all employees. An effective program should both educate and motivate employees as well as use aggressive management techniques to deter and detect willful misconduct.

\section{Applying Sentencing Guidelines to an FCPA Program}

The U.S. Federal Sentencing Guidelines for Organizations ${ }^{7}$ sets forth a framework for general compliance programs. A key element of such programs is a company code of conduct. The company must ensure that code provisions are adhered to and that the code is an effective tool to communicate company policy. Codes of conduct that are written hastily and then placed on a shelf rather than actively put into practice and enforced by management are inadequate with respect to the Sentencing Guidelines. Companies need to provide guidance, answering employee questions and ensuring that policies are understood and that employees agree to adhere to these policies. For companies with international locations, the code document should be translated into the local language.

To ensure employee adherence to the code, employees should be required to sign an acknowledgment form stating agreement to comply with code provisions.

The code should be required reading for all prospective consultants engaging in international work. The company should have a policy addressing the retention and use of agents and consultants, with set approval limits, required background checks (see "Investigative Due Diligence" in Part XII, below), as well as policies governing control over and management of the consultant. However, companies need to recognize that they should not depend on written policies alone; they need to play an active role in monitoring adherence. Please see Appendix A for sample code wording for sections relevant to FCPA compliance.

\section{Complance OVersight Responsibility}

An effective compliance program requires someone to take ownership of implementation as well as to monitor and ensure employee adherence. This individual must be a high-level member of management or a specially-appointed ethics officer 
who is well respected within the company. The audit committee should have active oversight and the compliance program should be authorized by board resolutions. Management committees should provide support to the compliance officer. Management committees are either officer-level committees that meet periodically, or committees at department head level and below, whose members may have more time to devote to compliance.

Another effective means of oversight is to have an on-site or business unit presence, often with "junior" compliance officers, liaisons or coordinators throughout the business. This is especially important for overseas locations separated from headquarters. The effect is to have the compliance program hit closer to home for the employees. Simply handing the compliance function over to company counsel will not have the needed impact or scope. The benefits of having a compliance officer include encouraging employees to raise questions, providing a central place to go if trouble arises and showing the government the company's senior-level involvement. Companies also need buy-in and active support by other senior managers.

\section{Investigative Due Diligence}

A typical step in an effective compliance program is to perform public record background investigations on potential hirees including checking for any criminal convictions. In addressing $F C P A$ risks, investigative due diligence must go one step further. Before hiring a foreign consultant, agent or representative, or entering into a foreign merger, acquisition or joint venture, companies should perform detailed investigative due diligence. Early detection is key to obtaining favourable treatment under the $F C P A$, as is monitoring relationships on an ongoing basis, and not just at the inception of a new business relationship.

The three elements of investigative due diligence are business and media database research, public records searches, and direct contact with government and industry sources. A fourth element, a detailed written disclosure and background questionnaire, can also provide critical information; problem relationships can be identified and references can be checked and verified.

Obtaining information in foreign countries may be difficult due to local regulations governing access, poor quality resources, or difficulties in accessing existing documents; however, it is possible to use investigative firms specializing in due diligence. These firms often have established local sources, such as local banks, accounting firms, industry experts and law enforcement personnel. In addition, inquiries should also be made of U.S. government agencies, the U.S. embassy commercial attaché, the Foreign Commercial Service of the Commerce Department, local counsel and bankers. Other areas for inquiry include: the reputation of the subject of the investigation for paying bribes; commission payments made outside the country; the willingness of the subject to accept contract provisions pertaining to FCPA compliance; any past affiliation of the subject with the government; employment by the government of relatives of the subject; requests for payment in cash to third parties; or, wire transfers to bank accounts in countries with bank secrecy laws. Additional areas for 
inquiry are relationships that involve unusually high commissions or agent requests to pick up cheques personally.

Although it is not insurance against fraudulent activity, companies should get representations or warranties from prospective agents or consultants agreeing to abide by FCPA provisions. Companies should include key clauses in contracts with agents and partners addressing compliance with laws and $F C P A$, or equivalent, standards. Contracts should include provisions for forfeiture of fees for violations, right to audit, cooperation in investigations and the right to control dealings with the government. Companies should find out if their partner, agent or consultant is connected to the government in any way and should follow up on this from time to time.

Companies with existing foreign agent or consultant relationships should consider disclosing such relationships to the government. If agents do not want the government to know they are representing the company, their reasons are most likely questionable. Furthermore, disclosing such relationships to the government can help to show that the company is acting in good faith.

\section{EFFECTIVE COMmUNiCATION OF STANDARDS}

To be understood by employees, written material must be clear, concise and interesting. The company needs to be sure to reach those employees who are located overseas and who may feel cut off from headquarters. One way to address current issues and keep all employees involved is to circulate reports of discipline cases, and answers to employee questions, in a company newsletter, transmitted via e-mail or the Internet.

Training performs two functions: information and motivation. Abiding by FCPA standards requires explaining of the rules to employees as well as informing employees that discipline can be severe. Beyond technical compliance with the law, employees should understand that the company's underlying goal is to conduct business with integrity. Employees should be asked to be on the lookout for, and report, any instances of other companies' misconduct, including bribery. Employees should understand that they are not alone and should be given reason to know the rules and implications of breaking the rules.

Training should be mandatory for international workers. Employees who have not attended the required training should not be permitted to travel internationally on behalf of the company. The most effective methods of training employees are live, on-site sessions involving role plays, question-and-answer sessions, videos and computer-based systems. Conducting sessions at foreign locations in small groups allows the trainer to find out what is going on and what is on the employees' minds. Including local counsel and discussion of local bribery law as part of FCPA compliance training educates employees that improper payment and record-keeping issues are not limited to U.S. law. 
Taking training one step further involves requiring agents to attend training. As discussed above, this can be a contractual requirement, and agents may opt to attend the company's in-house training or outside sessions.

\section{Xiv. Reasonable Steps to AChieve Compliance}

Active compliance monitoring combined with after-the-fact reviews and audits are necessary to effectively comply with the $F C P A$. In-house counsel and legal staff can serve as monitors. Existing internal auditors are good resources, but should be adequately trained to understand both the bribery and accounting provisions of the $F C P A$. These people should be trained to detect fraud, spot bribery issues and react to red flags.

Companies should have multiple sources of information for what is going on in each country and should consider having local sources report directly to headquarters in order to avoid control-oriented local management. Other fraud prevention techniques include regular monitoring of cash flows, mandatory vacations away from the office and rotation of personnel. Some companies have hotlines so employees can anonymously report incidents and ask questions. Employees should be informed that there will no be retribution for placing calls on the hotline.

\section{DisCiPLINE AND INCENTIVES}

Standards should be communicated clearly and the prospect of termination for infractions by any employee, regardless of position, made clear. Performance objectives can create strong pressure to violate the law. Compliance programs must address this fact. Compliance objectives must be specific, and employees should be encouraged to work cooperatively with the legal department, and to raise ethical questions as needed. The high-level compliance officer needs to respond appropriately to problems and incorporate the issues into the compliance program.

Investigations of allegations of wrongdoing should be timely and should not be performed by the same management teams that are accused of wrongdoing. If warranted, outside help can be an effective way to perform independent and effective investigations. In fact, the best approach for investigations may be a team of inside and outside talent. Companies should have a compliance crisis plan and consider a policy for voluntary disclosure.

\section{XVi. Industry Practice, Due Diligence AND EFfective Procedures}

Compliance programs should at least be up to industry practice standards, and companies should engage in benchmarking to determine what others are doing. This could include reviewing compliance literature or using outside compliance consultants.

Creating risk assessment and management plans are other ways to address the company's risks effectively. Management should identify the compliance and ethics 
risks in each new venture and should have a specific plan to deal with those risks. The plan should be developed by managers, with the advice of counsel. A key manager should be responsible for implementing the plan and this responsibility should be included in his or her appraisal review. The plan should identify the types of risks in a particular country, the types of training employees and agents should have, and the types of controls needed. The plan should also identify what other reputable U.S. companies are doing in that country. Necessary legal and audit resources, as well as processes for review and control of agents, should be described in the plan.

With respect to joint ventures and minority interests, the issue of controls should be raised early in the process and documented as part of the deal. Documentation should include procedures addressing due diligence, in order to prevent, detect and correct violations. There should be a due diligence folder on each agent or partner, accompanied by legal, audit and senior executive review. Companies should maintain records of training as well as of previous self-policing activity. It is not enough to merely have a compliance program in place. Companies must be able to prove their programs' effectiveness to a skeptical prosecutor, judge and public. 


\section{APPENDIX A}

\section{Foreign Governmental Payments}

1. It is the policy of the company to comply with the United States Foreign Corrupt Practices Act, and with local law applicable to governmental payments. Paragraphs 2, 3 and 4 set forth the company's policy with respect to certain aspects of the Foreign Corrupt Practices Act.

2. No employee shall directly or indirectly pay, give or offer money or anything of value to any foreign government officer, employee or representative, or to any foreign political party or candidate for or incumbent in any foreign political office, in order to assist in obtaining, retaining or directing business.

3. Notwithstanding the prohibition in paragraph 2 , an employee may make a facilitating payment to a foreign government officer, employee or representative, or to a foreign political party or party official, the purpose of which is to expedite or to secure the performance of a routine governmental action, if all of the following conditions are satisfied:

(a) such payment is nominal in amount;

(b) the routine governmental action to be expedited or secured is ordinarily and commonly performed by the officer, employee, representative, political party or party official receiving the payment;

(c) such routine governmental action does not include any decision or action relating to an award of or continuation of business; and

(d) such payment is approved in writing by the responsible $A B C$ manager.

"Responsible $A B C$ manager" in this provision means either:

(i) the president, representative director, manager director, general manager or comparable officer of ABC's affiliate in the country involved, or

(ii) the manager or director (whether regional, area, zone, country or other, but excluding sales representative) responsible in such country for the $\mathrm{ABC}$ division involved.

4. Also, the prohibition in paragraph 2 does not apply if the payment, gift or offer of money or anything of value is:

(a) a reasonable and bona fide expenditure, such as travel and lodging expenses, incurred by or on behalf of a foreign government officer, 
employee or representative, political party, or party official or candidate, and

(b) directly related to either:

(i) the promotion, demonstration or explanation of a product or service, or

(ii) the execution or performance of a contract with a foreign government or foreign government agency. 